\title{
Prophylaxis and Therapeutic Ability of Inactivated Dermatophytic Vaccine Against Dermatophytosis in the Rabbits as an Animal Model
}

\author{
Bir Hayvan Modeli Olarak Tavşanlarda Dermatofitoza Karşı İnaktive \\ Dermatofitik Aşının Profilaksi ve Terapötik Yeteneği
}

\author{
(D) Ali Abdul Hussein S. AL-JANABI ${ }^{1 *}$, (D) Falah Hasan Obayes AL-KHIKANI ${ }^{2}$ \\ ${ }^{1}$ Karbala University College of Medicine, Deparment of Microbiology, Karbala, Iraq \\ 2Al-Shomaly Teaching Hospital, Department of Microbiology, Babylon, Iraq
}

\begin{abstract}
Objectives: Dermatophytosis is a group of cutaneous diseases widely distributed in human and animals. It causes serious infection in some human cases and economic losses in farm animals. The primary aim of this study is to conduct an investigation of prophylaxis and a potential therapeutic vaccine against dermatophytosis.

Materials and Methods: The rabbit was chosen as an animal model of dermatophytosis for a case control study conducted in two parts. Inactivated cells of Trichophyton mentagrophytes were prepared for use as a vaccine. The prophylaxis part included vaccination of rabbits with the prepared vaccine either alone or with Freund's adjuvant, followed by infection with the same fungus. The second part included treatment of infected rabbits with an inactivated vaccine.

Results: The prepared vaccine showed prophylactic ability against infection with T. mentagrophytes for more than 6 months without requiringan adjuvant and also revealed at herapeutic ability in infected animals after a short time (16 days), compared with the control group.

Conclusion: Inactivated vaccine gives animals durable protection and shortens the treatmenttime for infection with dermatophytosis.

Key words: Dermatophytosis, Trichophyton mentagrophytes, vaccine, prophylaxis, rabbit
\end{abstract}

ÖZ

Amaç: Dermatofitoz, insan ve hayvanlarda yaygın olarak bulunan bir grup deri hastalığıdır. Bazı olgularda ciddi enfeksiyonlara ve çiftlik hayvanlarında ekonomik kayıplara neden olur. Bu çalışmanın temel amacı, profilaksi ve dermatofitoza karşı potansiyel bir terapötik aşı araştırması yapmaktır.

Gereç ve Yöntemler: Tavşan, iki bölümden oluşan bir olgu kontrol çalışması için dermatofitozun hayvan modeli olarak seçilmiştir. Trichophyton mentagrophytes'in etkisizleștirilmiş hücreleri, aşı olarak kullanılmak üzere hazırlandı. Profilaksi kısmı, tavşanların hazırlanan așı ile tek bașına veya Freund adjuvanı ile aşılanmasını ve ardından aynı mantarla enfeksiyonu içermiştir. İkinci kısım, enfekte tavşanların etkisizleştirilmiş bir aşı ile tedavisini içeriyordu.

Bulgular: Hazırlanan aşı, T. mentagrophytes ile enfeksiyona karșı 6 aydan fazla süreyle, bir adjuvana ihtiyaç duymadan profilaktik yetenek gösterdi ve ayrıca enfekte hayvanlarda, kontrol grubuna kıyasla kısa bir süre sonra (16 gün) terapötik yetenek gösterdi.

Sonuç: İnaktive aşı, hayvanlara kalıcı koruma sağlar ve dermatofitoz ile enfeksiyon için tedavi süresini kısaltır.

Anahtar kelimeler: Dermatofitoz, Trichophyton mentagrophytes, aşı, profilaksi, tavşan

\footnotetext{
*Correspondence: aljanabi_bio@yahoo.com, Phone: 07811411260, ORCID-ID: orcid.org/0000-0002-2479-3282

Received: 31.01.2020, Accepted: 05.07.2020

๑Turk J Pharm Sci, Published by Galenos Publishing House.
} 


\section{INTRODUCTION}

Nowadays, fungal infections are widely distributed and associated with serious mortality and morbidity rates all over the world. Most of these infections, especially the systemic types, are usually diagnosed too late to begin treatment. ${ }^{2}$ Thus, prophylaxis by vaccination against the most common fungal infections should take priority to limit the incidence of such diseases. For decades, antifungal vaccines have been considered impractical by most international scientific societies. ${ }^{1,3,4}$ Most attention has been focused on the development of vaccines against viral and bacterial infections., ${ }^{1,3}$ The reasons are that fungal infections usually show low incidence rates, and some of them are not widely distributed in comparison with bacterial and viral infections. ' Weakness of the immune system in most patients with fungal infections was also believed to decrease the efficacy of vaccines against fungi. ${ }^{3}$ However, to date, no vaccine had been licensed for use against a fungal infection in humans. ${ }^{4,5}$ Recently, this view has changed due growing interest in limiting a common type of fungal infection after its incidence increased, especially in immunocompromised patients or those with other predisposing factors., ${ }^{1,6}$ Several studies approved the suitability of vaccine development against common fungal infections such as those caused by Aspergillus spp., Candida spp., Paracoccidioides brasiliensis, Sporothrix spp., Cryptococcus spp., Coccidioides spp., Histoplasma spp., and Blastomyces spp.,6

Dermatophytosis is one of several skin diseases common in both humans and animals. ${ }^{7,8}$ It is caused by a special group of keratinophyllic fungi called dermatophytes. ${ }^{7}$ Although dermatophytosis is restricted to within a cutaneous layer of the skin, a systemic distribution in humans has been registered by many case studies. ${ }^{9-11}$ This development in the pathogenesis of dermatophytes directed specialists to consider dermatophytosis as a serious disease demanding increased attention. In animals, dermatophytosis is considered a very important disease due to its effect on the economic value of animal breeding. ${ }^{12}$ Although an effective vaccine against dermatophytosis is not a novel idea, research is ongoing for the ideal one with good prophylactic and therapeutic activity. Various components of dermatophytes have been evaluated as vaccines against dermatophytosis but have not received approval for commercial use in humans.13,14 However, these studies are still at an experimental level, even though a few of them are used commercially for various animals such as dogs, cats, bovines, and guinea pigs. ${ }^{13-26}$

Herein, rabbits were chosen as a model to investigate the suitability of a vaccine produced from Trichophyton mentagrophytes for prophylaxis and treatment of dermatophytosis.

\section{MATERIALS AND METHODS}

\section{Fungal isolate}

T. mentagrophytes was isolated from the tinea corporis of a 56-year old male for use in experimental infection of rabbits. The isolate was diagnosed by polymerase chain reaction (PCR) amplification and sequencing of the internal transcribed spacer region using the primer pair ITS1 (forward) and ITS4 (reverse). ${ }^{27}$ The fungal genome was extracted by using the FavorPrep ${ }^{T M}$
Fungi/Yeast Genomic DNA Extraction Mini Kit (Favorgen Biotech Corp., Taiwan).The PCR mixture was prepared in a total volume of $20 \mu \mathrm{L}$, including $5 \mu \mathrm{L}$ of AccuPower ${ }^{\circledR}$ PCR Premix (Bioneer, South Korea), $1 \mu \mathrm{L}$ of each primer, $1 \mu \mathrm{L}$ of template DNA, and sterile deionized distilled water. A negative control containing all reagent sexcept template DNA was also included. PCR cycling was initiated at $94^{\circ} \mathrm{C}$ for $2 \mathrm{~min}$, followed by 35 cycles of denaturation at $94^{\circ} \mathrm{C}$ for 35 seconds, annealing at $52^{\circ} \mathrm{C}$ for 30 seconds, and extension at $72^{\circ} \mathrm{C}$ for 60 seconds, with a final extension at $72^{\circ} \mathrm{C}$ for $6 \mathrm{~min}$. Sequencing of PCR the product was performed by Bioneer Company (South Korea). The fungal species was diagnosed after comparison of the obtained sequences with that recorded in GenBank by using the BLAST program.

\section{Vaccine preparation}

The antifungal vaccine was prepared from inactivated fungal cells of isolated from T. mentagrophytes. $100 \mathrm{~mL}$ of sterilized distilled water containing about $8 \times 10^{8}$ mature fungal cells [grown for 1 week at $30^{\circ} \mathrm{C}$ on Sabouraud's Dextrose agar (Himedia, India)] in each $\mathrm{mL}$ of D.W. was prepared

The aqueous fungal suspension was heated at $70^{\circ} \mathrm{C}$ for 3 hours in a water bath. ${ }^{28}$ To ensure inactivation of fungal cells, $0.1 \mathrm{~mL}$ of the treated fungal suspension was cultured on Sabouraud's Dextrose agar and incubated at $30^{\circ} \mathrm{C}$ for 2 weeks. The absence of growth is an indicator of successful inactivation. The prepared suspension was stored at $4^{\circ} \mathrm{C}$ until subsequent use as a vaccine. Freund's adjuvant of inactive Mycobacterium tuberculosis was chosen asthe adjuvant. It was used in two forms: initially as complete Freund's adjuvant and subsequently as incomplete Freund's adjuvant for the remainder of the experimental period.

\section{Animals}

A case control study was performed on rabbits to investigate the prophylactic and therapeutic potential of the dermatophytic vaccine. Ethical approval for this study was obtained from the Ethical Scientific Committee of the College of Medicine, University of Karbala, no. 504, on June 2, 2020. A total of 18 healthy rabbits weighing $2.5-3.5 \mathrm{~kg}$ were used in this study. For the prophylaxis study, 12 healthy rabbits were divided into four groups with 3 rabbits in each group. The first group was injected subcutaneously with $1 \mathrm{~mL}$ of vaccine only, the second with a mixture of $1 \mathrm{~mL}$ of vaccine and $0.1 \mathrm{~mL}$ of Freund's adjuvant (Wahag Al-Dna, Baghdad), the third with $0.1 \mathrm{~mL}$ of Freund's adjuvant only, and the fourth with neither vaccine nor adjuvant. Groups were infected later with isolated T. mentagrophytes, and the development of dermatophytosis was followed up. Clinical changes atthe infection site inall groups were observed for 6 months.

For the treatment study, six non-vaccinated rabbits infected with $T$. mentagrophytes were divided into two groups of three. The first group was treated with $1 \mathrm{~mL}$ of prepared dermatophytic vaccine by subcutaneous injection once daily for 16 days. The second group, used as a control, was left untreated. Clinical changes in infected lesions were followed up for approximately 3 months. 


\section{Infection of animals}

An inoculum solution containing $8 \times 10^{8}$ cells $/ \mathrm{mL}$ of $T$. mentagrophytes was prepared by mixing an amount of fungal mycelium grown on Sabouraud's Dextrose agar (Himedia, India) for 1 week at $30^{\circ} \mathrm{C}$ in sterilized normal saline. Counting was performed by the hemocytometer method. ${ }^{29}$ About $5-7 \mathrm{~cm}$ of the neck area of each rabbit was shaved by a mechanical method to remove covering hairs from the skin. A few drops of prepared fungal suspension were inoculated onto the shaved area with some pressure and spread on the skin surface by hand. Infection development was followed up for more than 3 weeks, when lesions were evaluated clinically as dermatophytosis infection.

\section{Statistical analysis}

All test data were expressed as mean \pm standard deviation. The values were analyzed statistically by One-Way ANOVA with Microsoft Windows Excel, version 10. The threshold for significance was set at $\mathrm{p}>0.05$.

\section{RESULTS}

The rabbit was chosen as a model to study the prophylactic and treatment efficacy of an antidermatophytic vaccine against dermatophytosis. In the prophylaxis control study, the first two groups of rabbits treated with the prepared vaccine and the vaccine together with Freund's adjuvant showed resistance to infection with $T$. mentagrophytes for more than 6 months, and there were no clinical features of infection or serious inflammatory responses to the adjuvant. Thus, the vaccine alone showed a successful immunization effect against dermatophytosis without the need for adjuvant. Mean while, rabbits treated with Freund's adjuvant only and control (untreated) rabbits revealed clinical features of dermatophytosis after 16 days from the start of infection (Table 1, Figure 1). In the second study, treatment of infected rabbits with the prepared vaccine was shown to be completely curative after 8 days. The number of lesions decreased gradually after vaccination until complete healing. Rabbits in the control group revealed no signs of cure, even after 3 months (Table 2, Figure 2).

\section{DISCUSSION}

The control of opportunistic fungal infections has been met with challenges due to an increase in the occurrence of these infections among a wide range of patients, especially immunocompromised individuals, cancer patients, those in long-term treatment, and premature infants. ${ }^{6}$ The development of resistance to antifungal agents is also associated with

\section{Table 1. Infection period of vaccinated rabbits}

\begin{tabular}{ll}
\hline Group & Infection period (days) \\
\hline Vaccine only & None* \\
\hline Vaccine with adjuvant & None* $^{\star}$ \\
\hline Adjuvant only & 16 \\
\hline Control & 16 \\
\hline
\end{tabular}

*Significant difference between groups at $p<0.05$ difficulty in their control., 40 Thus, a vaccine against infections by many pathogenic fungi is considered the best option to enhance the efficiency of the immune system.., 30 This has been taken seriously as an issue since our understanding of immunity toward pathogenic fungi has improved and the incidence and mortality rate of fungal infections has increased. ${ }^{6}$ Moreover, successful discovery of an antifungal vaccine will play an important role in limiting the use of chemotherapy or antifungal agents for the control of fungal infections. ${ }^{4}$ The main effective role of antifungal vaccines in the human body is to elevate the stimulation of immune system components against invasive fungi. Humoral immunity is the component of the immune system most affected by vaccine. ${ }^{7,31}$ This type of activation will provide protection to immunocompromised patients, especially after activation of antibody production.' Activation of cellular immunity represented by a Th1 response with induction of IL-12 and IFN- $\gamma$ is also required from an effective vaccine. ${ }^{30}$

Antifungal vaccine is usually prepared from living or inactivated whole cells, or from one component of fungi such as cell wall components, cytoplasmic extracts, and genetic recombinant proteins. ${ }^{32}$ Extensive studies have been performed to develop an effective vaccine against fungal infections in both man and animals. ${ }^{4.5}$ Although some vaccines are available for use in animals, researchers are still looking for a perfect vaccine. A satisfactory result has been achieved from vaccines used to immunize against various fungal diseases such as candidiasis,
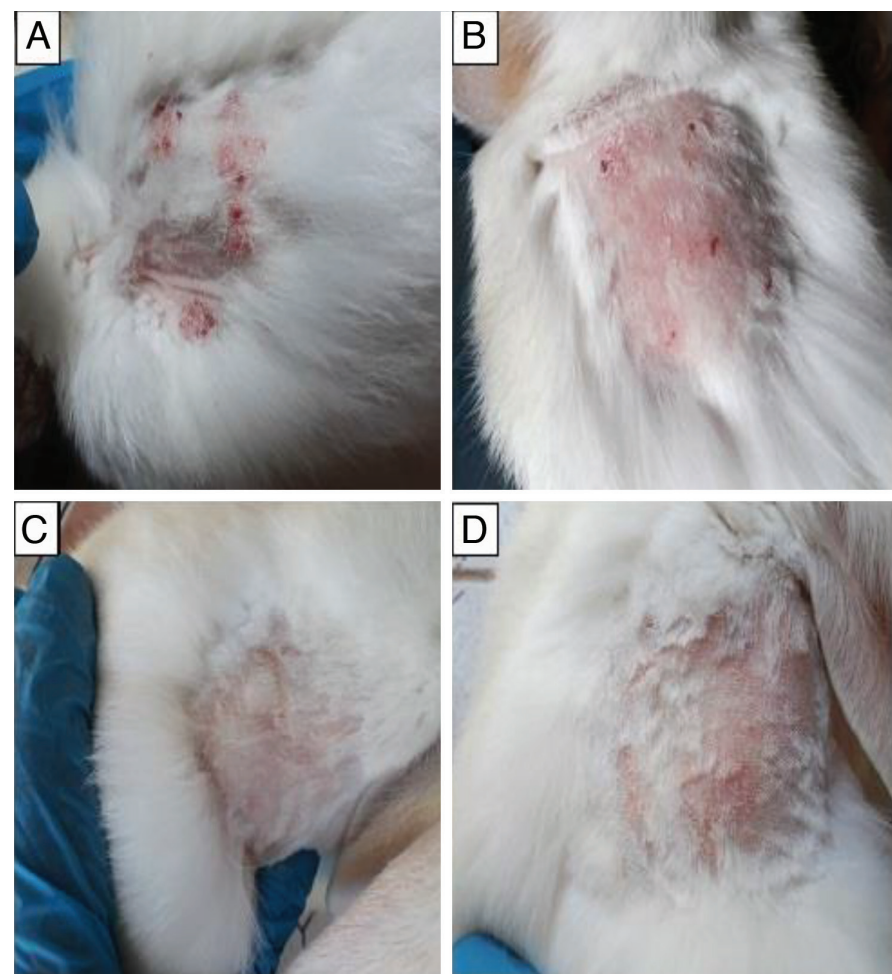

Figure 1. Infected rabbit with Trichophyton mentagrophytes after vaccination. A) Control rabbit with dermatophytosis lesions (red with granulated skin). B) Vaccinated rabbit with ad juvant only, which showed the same infectious features as the control. C) Vaccinated rabbit with vaccine ony without any lesions of dermatophytosis for more than 6 months. D) Vaccination with vaccine and adjuvant without any lesions of dermatophytosis for more than 6 months 
blastomycosis, coccidioidomycosis, histoplasmosis, and paracoccidioidomycosis. ${ }^{4}$ However, the United States Food and Drug Administration (US FDA) has not yet licensed any vaccine for commercial use. .,5,32 $^{-1}$

Dermatophytosis is a typical common disease in the cutaneous layer of the skin of different parts of the human or animal body. ${ }^{8}$ Control of this disease has recently gained attention after elevation of the drug-resistance rate in many causative dermatophytes ${ }^{33}$ and also because treatment of dermatophytosis, especially in animals, is usually expensive and time-consuming. ${ }^{7}$ Thus, the development of an anti-dermatophytic vaccine may

\section{Table 2. Treatment period of infected rabbits after vaccination}

\begin{tabular}{lll} 
Group & $\begin{array}{l}\text { No of lesions before } \\
\text { treatment }\end{array}$ & Treatment period (days) \\
\hline Vaccine only & $5-20$ & $8^{*}$ \\
\hline Control & $6-12$ & None \\
\hline
\end{tabular}

*Significant difference between groups at $p<0.05$
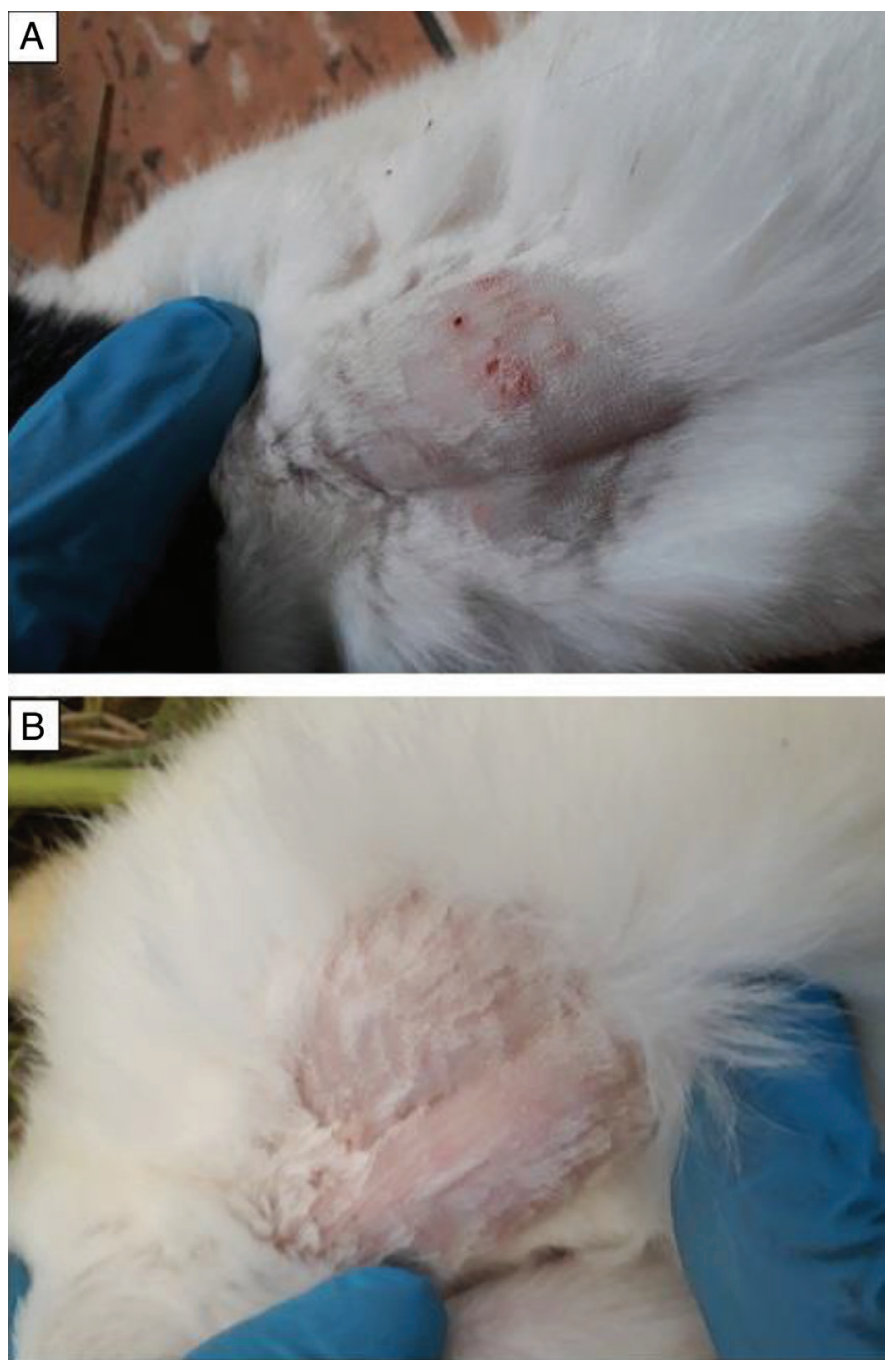

Figure 2. Treatment of infected rabbit with inactivated vaccine. A) Rabbit with dermatophytosis lesions before treatment. B) Rabbit with cure of infection after 8 days of treatment introduce a solution to decrease these disadvantages and also to limit the transfer of dermatophytes between humans and animals. ${ }^{7,34}$ However, increasing the immune response against dermatophytosis can be a key to limiting the toxicity and virulence effects of this disease. ${ }^{35}$ Recently, many studies have attempted to enhance the prophylactic action of the antifungal vaccine by stimulating cellular immunity to increase the immunization rate against dermatophytosis. ${ }^{8}$ This has been achieved by using specific antigens of a dermatophyte, especially those from Trichophyton spp., to provide stronger immunization than it can gain from inactive vaccine. ${ }^{7-8}$ Although no vaccine has a license for commercial use against dermatophytosis, some countries, such as Norway, immunize their cattle with a vaccine against Trichophyton verrucosum as a strategy to control dermatophytosis. ${ }^{7}$ The company Biocan M plus in the Czech Republic also produces an unlicensed vaccine from inactivated Microsporumcanis for the treatment of dogs against dermatophytosis. ${ }^{26}$

Our prepared vaccine provided prophylaxis to rabbits from dermatophytic infection for more than 6 months. Other studies failed to achieve this period;for example, the study of DeBoer and Moriello ${ }^{21}$ found that dermatophytosis lesions developed in cats vaccinated with killed $M$. canis cell wall after a 16-week challenge with other infected cats. The rabbit is often preferred for use as an animal model for fungal infection over small mammals due to the ease of observation of changes in fungal lesions. ${ }^{34}$ Vaccination of rabbits with culture filtrate antigens of one dermatophyte species was found to provide immunization against six other species, as indicated by a positive skin test. ${ }^{24}$ Subcutaneous injection of rabbits with heat-killed Trichophyton purpureum suspended in Freund's adjuvant also provided protection against infection bythe same fungus for more than 17 months. $^{36}$ Vaccination with heat-inactivated macroconidia

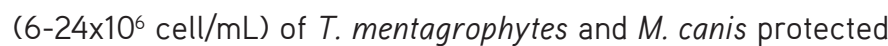
rabbits and guinea pigs against infection with a virulent isolate of $T$. mentagrophytes. ${ }^{15}$ Other animals have also shown resistance to infection with dermatophytes after immunization with antifungal vaccine. Vaccination of guinea pigs with Trichophyton equinum vaccine increased resistance to $M$. canis compared with non-vaccinated controls. ${ }^{24}$

In this study, vaccination was performed by inactive cells of $T$. mentagrophytes either alone or with adjuvant. This type of vaccine can exhibit a better outcome in some cases than from vaccination of animals with a specific component of

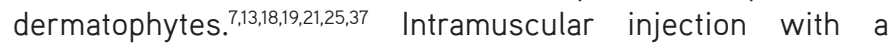
live vaccine of $T$. verrucosum was found useful to protect calves from dermatophytosis, ${ }^{18}$ while purified recombinant keratinolytic metalloprotease failed to protect guinea pigs against infection with $M$. canis. ${ }^{13}$ A freeze-dried preparation of live vaccine of $T$. verrucosum was also used successfully to protect calves against experimental dermatophytosis. ${ }^{25}$ Cats vaccinated with killed cell wall of $M$. canis showed efficiency at stimulating production of a high titer of anti-dermatophyte IgG and a weak cell-mediated response. ${ }^{21} \mathrm{~A}$ vaccine of whole cells of live and killed Aspergillus fumigatus also provided variable protection against aspergillosis in a mouse model. ${ }^{37}$ However, intra- or subcutaneous injection of whole cell or crude extract 
of dermatophytes has the ability to introduce greater protection in animals than when introduced by other routes. ${ }^{19}$

According to the results of this study, there was no difference between the use of prepared vaccine alone and with Freund's adjuvant. Both vaccinated groups of rabbits were resistant to infection by $T$. mentagrophytes for more than 6 months, while rabbits treated with only Freund's adjuvant showed infection after 16 days. This indicates that the presence of Freund's adjuvant had no effect on the prophylactic efficacy of prepared vaccine to stimulate the immune system. Westhoff et al. ${ }^{20}$ also found a similar result when they tested the prophylactic activity of non-adjuvanted inactivated vaccine in cats prepared from some strains of dermatophytes. In fact, the main reason to use Freund's adjuvant in this study was to increase potential immunologic stimulation by theprepared vaccine. Many studies have investigated the efficacy of antidermatophytic vaccines in animals after mixing them with adjuvant. Pier $^{23}$ found that a suspension of killed Trichophyton equinum with adjuvant showed effective prophylaxisin horses and guinea pigs against infection with the same fungus or with other species of dermatophytes. Adjuvanted secreted compounds of $M$. canis with monophosphoryl lipid-A revealed partial protection against infection with the same fungus in guinea pigs. ${ }^{14}$ In general, adjuvant, which contains one or more complex compounds, is preferred for use with a vaccine of a single antigen that has a weak ability to stimulate the immune response. ${ }^{4,36}$ Recently, researchers have attempted to develop an antifungal vaccine from purified, recombinant, or synthetic antigen, which all require adjuvant to obtain suitable protection against infection with pathogenic fungi. ${ }^{1,43}$ Unlike vaccines prepared with inactivated organisms, vaccines made from asingle antigen always have problems with purity and production.' Freund's adjuvant, which contains heatkilled Mycobacterium tuberculosis emulsified in mineral oil, is commonly used for accelerating new vaccine testing to stimulate immunity against various infections in animal experiments. ${ }^{1,4,31}$ This adjuvant role may maintain continual vaccine-stimulated immunity for a long period of time. By lengthening fungal antigen release into the injection site. ${ }^{38}$ Cellular immunity, such as that mediated by T-helper cells is usually elicited by Freund's adjuvant, which can also stimulate humoral immunity. 1,431,36 However, the combination of a vaccine with an adjuvant is used to achieve many purposes, including an increased immunological response through stimulation of various immunologic pathways; alteration of the immune response to a specific infection; and allowing the useof a small vaccine dose. ${ }^{31}$

In the second part of this study, the antifungal vaccine preparation showed therapeutic activity against dermatophytosis in rabbits in a short time (8 days), compared with the untreated group. In another study, a filtered culture of $T$. verrucosum was prepared as an injected vaccine with adjuvant for treatment of cows and buffaloes with dermatophytosis, and it showed effective results 10 days after injection. ${ }^{39}$ In a placebo-controlled, double-blind study, a mixed aqueous preparation of inactivated vaccine from six dermatophyte species exhibited better curative action for cats with dermatophytosis, especially those with a first infection or ata young age..$^{17}$ In activated vaccine of five species of dermatophytes without adjuvant was also used in another control study for treatment of cats with dermatophytosis, but no significant differences were observed between treated cats and a control group. ${ }^{20}$ Some companies are attempting to produce an effective prophylaxis and treatment vaccine against dermatophytosis in animals, but their work is still not licensed by the FDA. The Micanfin (Biocan-M ${ }^{\circledR}$ ) vaccine manufactured by Bioveta (Czech Republic), which is composed of inactivated $M$. canis, is used commercially to immunize cats and dogs against dermatophytosis. ${ }^{16,40}$ Erman Or et al. ${ }^{40}$ also found that the Micanfin product has therapeutic action against dermatophytosis in cats after two vaccination doses with a 21-day interval, while another study showed that this vaccine needed 20-30 days for treatment of cats with dermatophytosis. ${ }^{16}$ Meanwhile, Chansiripornchai and Suanpairintr ${ }^{22}$ found that treatment of a male cat with dermatophytosis with the Micanfin vaccine reduced infectious lesions and regrowth of hair 14 days after the first injection. Nedosekov et al. ${ }^{15}$ performed a clinical trial to evaluate the ability of the heat-inactivated vaccine of $T$. mentagrophytes and $M$. canis called Funhikanifel to immunize dogs and cats against experimental dermatophytosis. A single vaccination was followed by recovery of $27 \%$ of dogs, while double vaccination cured $96.8 \%$ of all animals.

The development of new vaccines for dermatophytosis in humanshas faced many challenges. First, the majority of fungal infections affect immunocompromised patients (this is not the case with dermatophytosis). This can be resolved by choosing a vaccine with the ability to elicit humoral immunity. Second, vaccine preparation has become expensive, especially for those prepared from recombinant antigens. Third, the new vaccine may act on the normal flora in the human body when it is used against diseases caused by one of them, for example candidiasis. Fourth, the use of an antigen similar toone present in the host that can induce an unnecessary autoimmune response and fifth, some types of vaccine either with or without adjuvant may not induce adequate immunization in some individuals. ${ }^{1,6,31,32,37}$

\section{CONCLUSION}

Although the search continues for a suitable vaccine against dermatophytosis, no one has a license from a regulatory organization such as the FDA for use in the commercial field. A new preparation of vaccine from inactivated $T$. mentagrophytes showed effective prophylaxis and treatment results against dermatophytosis in rabbits. Long-term protection and a short treatment time are the most significant results obtained from this study.

\section{ACKNOWLEDGMENTS}

The authors are grateful to Mr. Philip Smith for his assistance withlanguage corrections.

Conflicts of interest: No conflict of interest was declared by the authors. The authors alone are responsible for the content and writing of the paper. 


\section{REFERENCES}

1. Deepe GS Jr. Prospects for the development of fungal vaccines. Clin Microbiol Rev. 1997;10:585-596.

2. Yeo SF, Wong B. Current status of nonculture methods for diagnosis of invasive fungal infections. Clin Microbiol Rev. 2002;15:465-484.

3. Spellberg B. Vaccine for invasive fungal infections. F1000 Med Rep. 2011;3:13.

4. Portuondo DL, Ferreira LS, Urbaczek AC, Batista-Duharte A, Carlos IZ. Adjuvants and delivery systems for antifungal vaccines: current state and future developments. Med Mycol. 2015;53:69-89.

5. Edwards JE. Fungal cell wall vaccines: an update. J Med Microbiol. 2012;61:895-903.

6. Medici NP, Poeta MD. New insights on the development of fungal vaccines: from immunity to recent challenges. Mem Inst Oswaldo Cruz. 2015;110:966-973.

7. Gudding R, Lund A. Immunoprophylaxis of bovine dermatophytosis. Can Vet J. 1995;36:302-306.

8. Woodfolk JA. Allergy and dermatophytes. Clin Microbiol Rev. 2005;18:3043.

9. Lillis JV, Dawson ES, Chang R, White CR Jr. Disseminated dermal Trichophyton rubrum infection-an expression of dermatophyte dimorphism. J Cutan Pathol. 2010;37:1168-1169.

10. Warycha MA, Leger M, Tzu J, Kamino H, Stein J. Deep dermatophytosis caused by Trichophyton rubrum. Dermatol Online J. 2011;17:21.

11. Kim S, Jo IH, Kang J, Joo SY, Choi J. Dermatophyte abscesses caused by Trichophyton rubrum in a patient without pre-existing superficial dermatophytosis: a case report. BMC Infect Dis. 2016;16:298.

12. Mousa WS, Eman-Abdeen. Review: overview on bovine dermatophytosis. International J Veterinary Sciences and Animal Husbandry. 2018;3:16-19.

13. Vermount SM, Brouta FD, Descamps FF, Losson BJ, Mignon BR. Evaluation of immunogenicity and protective efficacy of a Microsporum canis metalloprotease subunit vaccine in guinea pigs. FEMS Immun Med Microbiol. 2004:40:75-80.

14. Cambier L, Băgut ET, Helinen MP, Tabart J, Antoine N, Mignon B. Assessment of immunogenicity and protective efficacy of Microsporum canis secreted components coupled to monophosphoryl lipid-A adjuvant in a vaccine study using guinea pigs. Vet Microbiol. 2015;175:304-311.

15. Nedosekov V, Martynyuk O, Stetsiura L, Evaluation of manufacturing specification of antifungal vaccines. Eduk Tech Inform. 2016;7:158-162.

16. Kurtdede A, Ural K, Gazyagci S, Cingi CC.. Usage of inactivated Microsporum canis vaccine in cats naturally infected with M. canis. Mikol Lek. 2007;14:19-21.

17. Westhoff DK, Kloes MC, Orveillon FX, Farnow D, Elbers K, Mueller RS. Treatment of feline dermatophytosis with an inactivated fungal vaccine. Open Mycol J. 2010;4:10-17.

18. Mikaili A, Chalabi M, Ghashghaie A, Mostafaie A. Immunization against bovine dermatophytosis with live Trichophyton verrucosum. Afr J Microbiol Res. 2012;6:4950-4953.

19. Grappel SF, Bishop CT, Blank F. Immunology of dermatophytes and dermatophytosis. Bacteriol Rev. 1974;38:222-250.

20. Westhoff D, Orveillon FX, Farnow D, Klös MC, Elbers K. Safety of a non-adjuvanted therapeutic vaccine for the treatment of feline dermatophytosis. Vet Rec. 2010;167:899-903.
21. DeBoer DJ, Moriello KA. Investigations of a killed dermatophyte cell-wall vaccine against infection with Microsporum canis in cats. Res Vet Sci. 1995;59:110-113.

22. Chansiripornchai P, Suanpairintr N. Treatment of Microsporum canis infection in a cat using a fungal vaccine. Thai J Vet Med. 2015;45:645-649.

23. Pier AC. Dermatophyte vaccine. United State Patent. No. 5,284,652 in Feb. 8, 1994. Available from: https://patents.justia.com/patent/5284652

24. Pier AC, Hodges AB, Lauze JM, Raisbeck M. Experimental immunity to Microsporum canis and cross reactions with other dermatophytes of veterinary importance. J Med Vet Mycol. 1995;33:93-97.

25. Rybnikáŕ A, Chumela J, Vrzal V. Effect of culture age on protective potency of a vaccine against bovine ringworm prepared of Trichophyton verrucosum. Acta Vet Brno. 2002;71:51-53.

26. Bioveta. Inactivated vaccine against mycolic disease caused by Microsporum canis in dogs. Biocan M Plus, Injection suspension for dogs. 2016. Available from: https://www.bioveta.eu/products/veterinaryproducts/biocan-m-plus-injection-suspension-for-dogs.html

27. White TJ, Bruns T, Lee S, Taylor J. Amplification and direct sequencing of fungal ribosomal RNA genes for phylogenetics. In: Innis MA, Gelfand DH, Sninsky JJ, White TJ, eds. PCR protocols: A guide to methods and applications. New York: Academic Press; 1990:315-322.

28. Martinez M, Clemons KV, Stevens DA. Heat-killed yeast as a pan-fungal vaccine. Methods Mol Biol. 2017;1625:23-30.

29. AL-Janabi AA. Determination of antidermatophytic effects of nonsteroidal anti-inflammatory drugs on Trichophyton mentagrophytes and Epidermophyton floccosum. Mycoses. 2011;54:e443-e448.

30. Cutler JE, Deepe GS Jr, Klein BS. Advances in combating fungal diseases: vaccines on the threshold. Nat Rev Microbiol. 2007;5:13-28.

31. Coffman RL, Sher A, Seder RA. Vaccine adjuvants: putting innate immunity to work. Immunity. 2010;33:492-503.

32. Hamad M. Universal fungal vaccines, could be light at the end of the tunnel? Hum Vaccin Immunother. 2012;8:1758-1763.

33. Martinez-Rossi NM, Bitencourt TA, Peres NT, Lang EA, Gomes EV, Quaresemin NR, Martins MP, Lopes L, Rossi A. Dermatophyte resistance to antifungal drugs: mechanisms and prospectus. Front Microbiol. 2018;9:1108.

34. Capilla J, Clemons KV, Stevens DA. Animal models: an important tool in mycology. Med Mycol. 2007;45:657-684.

35. Criado PR, Dantas KC, Benini LV, de Oliveira CB, Takiguti FA, Vasconcellos C. Superficial mycosis and the immune response elements. An Bras Dermatol. 2011;86:726-731.

36. Wharton ML, Reiss F, Wharton DR. Active immunization against Trichophyton purpureum infection in rabbits. J Invest Dermatol. 1950;14:291-303.

37. Levitz SM. Aspergillus vaccines: hardly worth studying or worthy of hard study. Med Mycol. 2017;55:103-108.

38. Josefsberg JO, Buckland B. Vaccine process technology. Biotechnol Bioeng. 2012;109:1443-1460.

39. Mousa WS, Abdeen E. Evaluation of new compounds efficacy on dermatophytosis treatment in cattle and buffalo. Dairy and Vet Sci J. 2018;7:555708.

40. Erman Or M, Özkan B, Kayar A, Ikiz S, Özgür Y, Morkoç T, Dodurka T. Immunotherapeutic influence of Micanfin (Biocan-M ${ }^{\circledR}$ ) used for immunoprophylaxis in dermatomycosis. Mikol Lek. 2005;12:71-73. 